Jurnal ASPIKOM, Vol. 7, No. 1, January 2022, pp. 84-97

P-ISSN: 2087-0442, E-ISSN: 2548-8309

DOI: http://dx.doi.org/10.24329/aspikom.v7i1.1051

\title{
Online Media to Address Violence against Women during COVID-19 Pandemic
}

\author{
Kristina Andryani*, Felicciana Yayi Amanova, Rosalia Prismarini \\ Universitas Mercu Buana Yogyakarta, Jl. Ring Road Utara, Sleman, Yogyakarta \\ Indonesia \\ *Corresponding author, e-mail: kandryani@mercubuana-yogya.ac.id
}

\begin{abstract}
This research aims to identify obstacles and analyze the strategic solution taken by the Public Relations of Rifka Annisa's Women Crisis Center in utilizing online media platforms to address violence against women during the Covid-19 Pandemic in Yogyakarta. This research uses the qualitative case study method through observation and in-depth interviews at the Public Relations division of Rifka Annisa. Crisis Management and New Media concepts are used to analyze strategies in addressing the problem. The research results reveal that the outbreak of the Covid-19 pandemic has triggered the rise of violence against women. Social restriction during the pandemic is an obstacle for Rifka Annisa in reaching the violence victims and the wider community. Rifka Annisa shifts their usual face-to-face counseling programs for violence victims to online counseling programs. Similarly, they use online media platforms to advocate for public awareness, where they selectively select the online media type that suits the character of the target audience.
\end{abstract}

Keywords: COVID-19 Pandemic; Crisis Management; Online Media; Public Relations; Violence against Women

\begin{abstract}
Abstrak
Penelitian ini bertujuan untuk mengidentifikasi kendala dan menganalisis solusi strategis yang diambil oleh Public Relations Rifka Annisa Women's Crisis Center dalam memanfaatkan platform media online untuk mengatasi kekerasan terhadap perempuan selama Pandemi Covid19 di Yogyakarta. Penelitian ini menggunakan metode studi kasus kualitatif melalui observasi dan wawancara mendalam pada bagian Humas Rifka Annisa. Konsep Crisis Management dan New Media digunakan untuk menganalisis strategi dalam mengatasi masalah tersebut. Hasil penelitian mengungkapkan, merebaknya pandemi Covid-19 memicu peningkatan kasus kekerasan terhadap perempuan. Pembatasan sosial di masa pandemi menjadi kendala bagi Rifka Annisa dalam menjangkau para korban kekerasan dan masyarakat luas. Rifka Annisa mengalihkan program konseling tatap muka bagi korban kekerasan ke program konseling daring. Demikian pula, mereka menggunakan platform media online untuk mengadvokasi kesadaran publik, di mana mereka secara selektif memilih jenis media daring yang sesuai dengan karakteristik target audiens.
\end{abstract}

Kata Kunci: Pandemi COVID-19; Manajemen Krisis; Media Online; Public Relations; Kekerasan terhadap Perempuan 


\section{Introduction}

The United Nations defines violence against women as any act of gender-based violence that results in or is likely to result in physical, sexual, or psychological harm or suffering to women, including threats of such acts, coercion or arbitrary deprivation of liberty, whether occurring in public or in private life (United Nations Women, 2016). Such acts of violence also often occur to children. A study by Devries et al. in 2018 towards 600 populations representing 171 countries revealed that children and adolescents aged 2-19 years experience violence in their daily interactions in the family, school, and social environment, where the violence perpetrators are the closest people or those who have authority such as parents, teachers, and boyfriends (Devries et al., 2018). Violence against women is rooted in the manifestation of historically unequal power relations between men and women, leading to men's domination and discrimination against women and continuing to hold back women's development. Spotting the complex socio-cultural roots requires the synergy of various parties such as government agencies, Non-Governmental Organizations (NGOs), and the wider community to overcome these social problems (Andina et al., 2020; United Nations Women, 2016).

The outbreak of the Covid-19 pandemic exacerbates the vulnerability of women to various forms of violence. Especially during the 2020 lockdown policy, cases of genderbased violence increased in America, Europe, Australia, and Asia, where women and children frequently experience physical violence, sexual violence, and even murder. The economic impact of the Covid-19 pandemic on society, such as reduced income, job loss, and situations of uncertainty, have triggered pressure, stress, and violent behavior. In response to this crisis, governments in many countries use a variety of possible means to reach the community to reduce the number of cases of gender-based violence. For example, the Australian and European governments have allocated millions of dollars to provide accommodation facilities for violence victims, counseling posts in public places such as pharmacies and supermarkets, building mobile applications that connect people to the police, and organizations that assist violence victims. In India, the government provides more than 50 helplines that can be reached through various mobile applications and emergency telephone lines to direct violence victims to shelters for physical and legal protection (Andina et al., 2020; Pearson et al., 2021). Not only the government, are non-profit organizations also actively responding to the increase of violence against women and children during the Covid-19 pandemic. Most non-profit organizations in European countries reach the violence victim through online media features and mobile applications and provide psychological and legal support through online platforms such as Zoom and Skype. They also actively appear on television programs, news channels, and radio advertisements to promote awareness of violence against women and children during the pandemic (Pearson et al., 2021).

In Indonesia, violence against women is nothing new. Indonesian National Commission on Violence against Women noted that cases of violence against women increased by $792 \%$ within 12 years, which means that in actual situations, women in Indonesia are not safe from gender-based violence (Komnas Perempuan, 2020). In the initial period of the pandemic, from March 2 to April 26, 2020, acts of violence against women in Indonesia reached 173 cases, with an average of 3 cases per day (Kemen PPPA, 2020). Some of the obstacles in dealing with these cases are that most victims of violence do not know how to seek help or report their situation. Also, there are cultural factors in some societies that perceive acts of violence or harassment in their domestic 
environment as a disgrace that is inappropriate to be disclosed (Andina et al., 2020).

The discourse of violence against women in Indonesia is handled by a government institution and women's NGOs. One of the NGOs competent in this discourse is Rifka Annisa Women's Crisis Center. Located in Yogyakarta, Rifka Annisa has been around for 28 years focusing on handling victims of violence against women and advocating public awareness towards these social problems. Rifka Annisa's vision and mission are implemented in proactive, educative, and technology-responsive work programs. They intensively accommodate violence victims through psychological and legal counseling programs and are proactive in encouraging government policies towards protecting women. They also educate the public through workshops, training, interactive websites, and social media campaigns. The Public Relations Division plays a significant role in Rifka Annisa's work performance, where the public relations practitioner is the frontman in implementing Rifka Annisa's work programs and overcoming obstacles. This research will examine how Rifka Annisa's public relations division applies crisis management measures and utilizes online media platforms to carry out its work agenda, especially with the increase in violence cases during the Covid-19 pandemic in Yogyakarta.

In developing this research, the researchers took insights from several previous studies that examined the performance of Public Relations in NGOs in overcoming the discourse of violence against women. Research by Dr. Anshu Bhati in 2012 entitled "Role of Public Relations for Effective Communications in NGOs" examined the role of Public Relations in achieving the communication objectives of Indian NGOs. This study was conducted on 105 NGOs in India by mapping their working areas, communication practices, the groups they communicate with, and their communication objectives. This research found that NGOs have an important need to communicate with internal and external publics for their sustainability in a constantly evolving environment. At this point, Public Relations becomes the main vehicle that can fulfill the needs because Public Relations has strategic steps that can reach the wider community and stakeholders effectively and efficiently, both directly and through media relations. As stated by Bhati, "PR has many tools in its basket which have a personal touch that increases trust and faith and at the same time allows NGO sector to reach public at meager cost" (Bhati, 2012).

Ali, Boddy, O'Leary, \& Ewart, in their research entitled "Exploring the use of public relations in organising activism: Implications for addressing gender-based violence in the developing world" in 2016, discussed the use of Public Relations in organizing activism to address gender-based violence and create positive social change in some developing countries. The researchers concluded five main points about how activists use Public Relations to organize activism against gender-based violence, as follows:

1. Public Relations is used by activists to organize society and changes in behaviour,

2. Activists often play the role of Public Relations workers in their campaigns,

3. Public Relations is used by activists as a strategic communication tool with victim narratives,

4. Public Relations serves as a framing tool for activism, and

5. Public Relations makes the activism visible to the general public.

In each point, the researchers found that Public Relations contributes greatly as a strategic communication method and as an individual communicative technique for 
organizing activists in promoting gender-based violence discourse to gain public support and create positive social change (Ali et al., 2016).

Furthermore, research by Akhmed Khamis Kaleel Kaleel in 2020 entitled "Role of public relations in crisis management with the coronavirus crisis as an example: A case study on the UAE" observed the solutions applied by the United Arab Emirates (UAE) government to manage the coronavirus crisis through public relations strategies. This research highlighted some of UAE's vital areas: health, education, and tourism in crisis management during the Coronavirus outbreak, where the UAE government took transparency measures to its citizens. In crisis management, the Public Relations Department of the Ministry of Health of UAE played an active role in spreading awareness and accurate news about the status of the coronavirus in their country. The agenda includes holding daily press conferences to inform the number of deaths and recoveries; conducting questionnaires to find out community reactions to preventive measures; providing news updates regarding the coronavirus crisis on the Ministry of Health official website to assist the authorities in making the right decisions based on accurate information; and publishing all indicative and awareness data on social media and mainstream media in the country to convey the true and accurate messages to the public. The study result found that involving the role of Public Relations to deal with the Coronavirus outbreak in UEA has significantly reduced the impact of the crisis at all levels (Kaleel, 2020).

Several previous studies above show that Public Relations contributes strategically to the NGO sector, including NGOs engaged in gender-based violence discourse. However, until this research was conducted, the researchers have not found any research that examines the performance of Public Relations in NGOs in overcoming the discourse of violence against women during the Covid-19 pandemic. The researchers also have not found any research that specifically discusses the use of online media in this discourse. Therefore, the novelty of this research is examining the performance of Rifka Annisa's Women Crisis Center Public Relations in overcoming cases of violence against women in the recent Covid-19 pandemic in Yogyakarta. This research aims to identify the obstacles Rifka Annisa during the pandemic situation and analyze the strategic step of Rifka Annisa in utilizing online media as a solution in managing the crises or obstacles.

Due to various government-imposed social restrictions since the beginning of the Covid-19 pandemic, Rifka Annisa had to stop all their field activities such as face-toface counseling for violence victims at the office, home visits, and public advocacy. Thus, it becomes an obstacle in reaching clients and the wider community to continue their work program that has been going well so far. The condition has worsened with the increase in violence against women and children during the pandemic, forcing Rifka Annisa to make many adjustments in their work program as a strategic solution in overcoming the ongoing crisis. The researchers used the concept of Crisis Management and New Media to analyze Rifka Annisa's Public Relations strategy in addressing the obstacles.

Public Relations is an essential tool for the management of various institutions. Public Relations Division responds to internal and external crises within an institution so that the performance and image of the institution can be at its best. When a crisis occurs, Public Relations should give an immediate response by paying attention to any information or news related to the crisis circulating in the mass media and society and providing explanations to clarify the information by using all forms of mass media. 
According to Firsan Nova (2011), crisis management can be performed by taking the following steps:

1. Forecasting; crisis forecasts need to be carried out in pre-crisis situations. This step can be conducted by identifying and analyzing opportunities and threats in the business world. Rifka Annisa has two main work agendas, namely facilitating victims of violence and advocating for public awareness regarding the discourse of gender-based violence. Public Relations Rifka Annisa identifies and maps the needs of each work agenda to develop appropriate programs to achieve the goals of the work agenda, as stated by Rifka Annisa's Public Relations practitioners, "We have a wide audience segmentation with different levels of needs and understanding: children; teenager; adults; parents. In facilitating the violence victims, the assistance we provide, such as psychological counseling and legal assistance, will be adjusted to the segmentation of the audience and the cases of violence they have experienced. Similarly, in advocating public awareness, we build segmented education and outreach programs. For example we have a workshop program for students, and a mentored program for parents in several sub-districts in Yogyakarta".

2. Prevention; preventive measures should be applied in pre-crisis situations to prevent situations from becoming a crisis. Rifka Annisa's Public Relations applies preventive measures in line with forecasting steps. Building work programs by first identifying and mapping the needs of audience segmentation is a preventive step to minimize obstacles that can disrupt their work rhythm in achieving the goals of the work agenda.

3. Intervention; in a crisis situation, intervention measures are taken to end the crisis. Crisis is not always negative but can also develop positively. Rifka Annisa's Public Relations performs the intervention stage when obstacles can potentially disrupt the work rhythm of their ongoing programs. For example, when Rifka Annisa's field activities had to stop due to the social distancing policy during the Covid-19 pandemic, Rifka Annisa's Public Relations made many adjustments by shifting to online programs.

Besides the Crisis Management concept, the researchers used the New Media concept to analyze the strategic solution taken by Rifka Annisa in addressing the obstacles that arose during the covid-19 pandemic. Nowadays, everyone depends on the need for information technology. New media provide unlimited possibilities in all areas of life. It offers new communication technologies to obtain and convey information to target audiences, new ways to interact, new technologies to shape public opinion and behavior (Kazak et al., 2017). Rogers (1986) in Rahardjo (2011) described three main characteristics of new communication technology, namely: Interactivity, is the ability of a new communication system to talk back to its users, almost like someone's participation in a conversation; Demassification, meaning that control over the mass communication system usually shifts from message producers to media consumers; and Asynchronous, meaning that the new communication technology can send and receive messages at any time the user wants (Rahardjo, 2011). Judging from its characteristics, new media platforms have the advantage of providing fast, real-time interaction facilities; ease of exchanging information; and the power to shape audience behavior. These advantages can overcome the limitations of social activities due to the social restriction policy during the Covid-19 pandemic. Therefore, Rifka Annisa's Public Relations utilizes new media platforms such as social media and online messaging 
applications to carry out a series of activities for their work programs during the pandemic.

\section{Method}

This research was conducted in Yogyakarta in June - August 2021. This research is a case study qualitative research. The researchers used the intrinsic case study approach to analyze the crisis management implemented by the Rifka Annisa Women's Crisis Center Public Relations in overcoming the increase in cases of gender-based violence and the limited social activities due to the Covid-19 pandemic in Yogyakarta. The research object is the Public Relations Division of Rifka Annisa Women's Crisis Center. The research subject is the Public Relations Practitioner of Rifka Annisa Women Crisis Center, Mrs. Dewi Julianty. Data collection techniques used are in-depth interviews to obtain primary data and observation methods to obtain secondary data. An in-depth interview was conducted by having a direct interview with Rifka Annisa's Public Relations practitioner to explore information that includes opinions, motivations, values, or experiences of the informant. The researchers have relatively no control over the informant's response during the interview, which means the informant is free to express her opinion or answer. Observations were made by systematically observing the phenomenon of increasing cases of violence against women and children during the Covid-19 pandemic. Observations were also made on Rifka Annisa's social media accounts to see their activities in conducting online advocacy related to the phenomenon.

Furthermore, this research employs data analysis technique of interactive model, which consists of three components:

1. Data condensation (data reduction); refers to the filtration of information compiled during data collection through transcription, coding, narrative summaries, theme development, written analytic memos, and generation of categories (Miles et al., 2014). The researcher selects primary and secondary data into groups of data relatable to the research objectives, including sorting out data out of focus for the research objectives.

2. Data display; refers to an organized, condensed compilation of information that enables the researcher to draw cogent conclusions categories (Miles et al., 2014). Researchers present data in the form of narrative texts and descriptive explanations.

3. Conclusion drawing and verification; refers to finding meaning and facts from data finding answers to research problems by analyzing and cross-checking the data (Miles et al., 2014). The researcher analyzes the data findings to answer the research objectives, rechecks the suitability of the analysis with the findings, and then finally concludes the research objectives.

\section{Results and Discussion}

From January to September 2020, Rifka Annisa has received 660 cases of violence against women, 579 cases of which occurred during the Covid-19 pandemic. The cases include violence against wives, violence in dating, violence within family members, sexual harassment, rape, and trafficking (Rifka Annisa WCC, 2020).

Furthermore, based on interviews with informants, the researchers found that the pandemic period poses more significant challenges in dealing with gender-based violence because the pandemic situation creates new patterns that lead to acts of violence against women and children: first, declining economic condition as a result of 
the pandemic such as lay-offs, business closure, etc. have triggered domestic violence where the wife tends to be the target of her husband's anger who feels pressured due to financial difficulties during the pandemic, as stated by the research informant,

"We handle the most cases of violence against wives, especially during this pandemic, there is a lot of family neglect and physical violence against wives. The meeting intensity of family members becomes more frequent when the husband is at home due to the impact of the pandemic, it triggers negative emotions, and even our clients (wives) are beaten, slapped, scolded by their husbands."

Second, increasing cases of gender-based violence such as sexual harassment in virtual spaces happen because, during the pandemic, people interact more often in social media and messaging applications. Such cases of cyber-based violence are often experienced by teenagers and adult women. The violence perpetrators are generally people who are close to the victim, such as boyfriends and friends, or other people who are not familiar with the victim. The research informant explains this condition,

"...on the other hand, during this pandemic, teenagers spend more time than usual accessing many online platforms because teens are gadget literate. This interaction leads to many cases of online gender-based violence via WhatsApp and other social media. For example, teenagers dating and having sexual relations are then threatened by their partners, who will share their sex videos/photos on social media. Another case that frequently occurs is verbal harassment in virtual rooms."

Responding quickly to problems is the primary action of the Public Relations Division of Rifka Annisa. It is in accordance with the stages in overcoming the crisis that even a small problem can develop into a crisis if it is not managed properly with a serious action (Devlin, 2006). To face problems that arise in pandemic situations, such as a significant increase in the number of cases of gender-based violence while at the same time a series of field activities had to be stopped due to social restriction, the Public Relations Division of Rifka Annisa integrates with other internal divisions, directing their work program to an online platform. For example, counseling for clients (violence victims) that cannot be conducted face-to-face during the pandemic are bridged by opening personal counseling services via telephone lines, WhatsApp applications, and e-mail, as explained by the informant:

"At the beginning of the Covid-19 pandemic in Yogyakarta, we have started to switch to hotline services and online counseling via WhatsApp or e-mail. The hotline numbers are held directly by our counselors. However, if there are old or new clients with a certain urgency, we can arrange face-to-face counseling, of course by strictly following the health protocol. We have prepared a special counseling room that meets the health protocol requirements, just in case we get clients who absolutely cannot be handled online. Not only for the clients but we also provide the counselors' health needs, so they are not easy to be exposed to the virus."

From the explanation, the researcher analyzed that Rifka Annisa's Public Relations has implemented the stages of crisis management well. In the pre-crisis situation, Rifka Annisa applied the forecasting step by mapping the potential problem. They noticed that the outbreak of the Covid-19 pandemic followed by social restrictions would stop face-to-face client handling activities. Rifka Annisa then takes preventive measures by intensively facilitating client needs through online media facilities and preparing a special room that adapts health protocols to handle clients in emergencies.

Online Media to Address Violence against Women during COVID-19 Pandemic (Kristina Andryani) 
In addition, online counseling services are provided in several forms of media. This shows that Rifka Annisa is trying their best to make clients able to be in touch with the counselor through the types of media according to the convenience of each client. Furthermore, the intervention step, which aims to end the crisis, is conducted by Rifka Annisa by carrying out online work activities arranged at the pre-crisis stage. Taking these crisis management steps allows Rifka Annisa to continue her work program in various limitations during the pandemic, along with the increasing number of cases of gender-based violence.

However, the implementation of these strategic steps does not always run smoothly. There are still obstacles, such as some clients are still confused or reluctant to contact the counselor through online media so that the handling of cases or counseling becomes disconnected and unresolved. Responding to this problem, Rifka Annisa actively tries to contact clients via telephone or messaging applications. Therefore, counseling activities can be continued while encouraging clients to adapt in the transition from face-to-face counseling to counseling through electronic media during the pandemic; as the informant stated,

"...however, the pandemic broke out so suddenly that there was not much time in the transition from face-to-face counseling to online counseling. Some of our clients, especially old clients, feel uncomfortable doing online counseling or do not understand how to contact us online so that the case is not resolved. At the same time, they still need psychological or legal assistance. When they lose contact, we take the initiative to contact them as much as possible and make them comfortable with online counseling methods."

Aside from helping the victim of gender-based violence through psychological and legal counseling, Rifka Annisa also has a series of work programs advocating public awareness of gender-based violence. Their advocacy activities, originally carried out through face-to-face workshops and training programs, have now shifted to virtual or online activities due to social distancing policies during the Covid-19 pandemic. Similar to the strategic steps applied to their online counseling programs, Rifka Annisa's Public Relation utilizes various new media platforms as much as possible so that the educational materials can effectively reach the target audience. By its nature, social media is a communication tool that can reach the widest community. It is widely known that social media is often used to reach and influence the target audience in achieving various political, commercial, socio-cultural interests in the public sector, including the non-profit sector.

On the other hand, social media platforms have their unique features, which classify users from various aspects such as age, gender, and interests. Therefore, it emphasizes the immense and almost limitless ability of social media platforms in reaching the relevant public (Curtis et al., 2009; Baruah, 2012; Karlsen \& Enjolras, 2016; Raudeliuniene et al., 2018). Rifka Annisa's Public Relations initiated a series of public education through webinars and creative discussions initiated through Instagram, Youtube, and Zoom, where the aim is to provide young people with a better understanding and knowledge about violence against women. Several examples of Rifka Annisa's educational activities in the virtual space are as follows:

Jurnal ASPIKOM, Vol. 7, No. 1, January 2022, pp. 84-97 

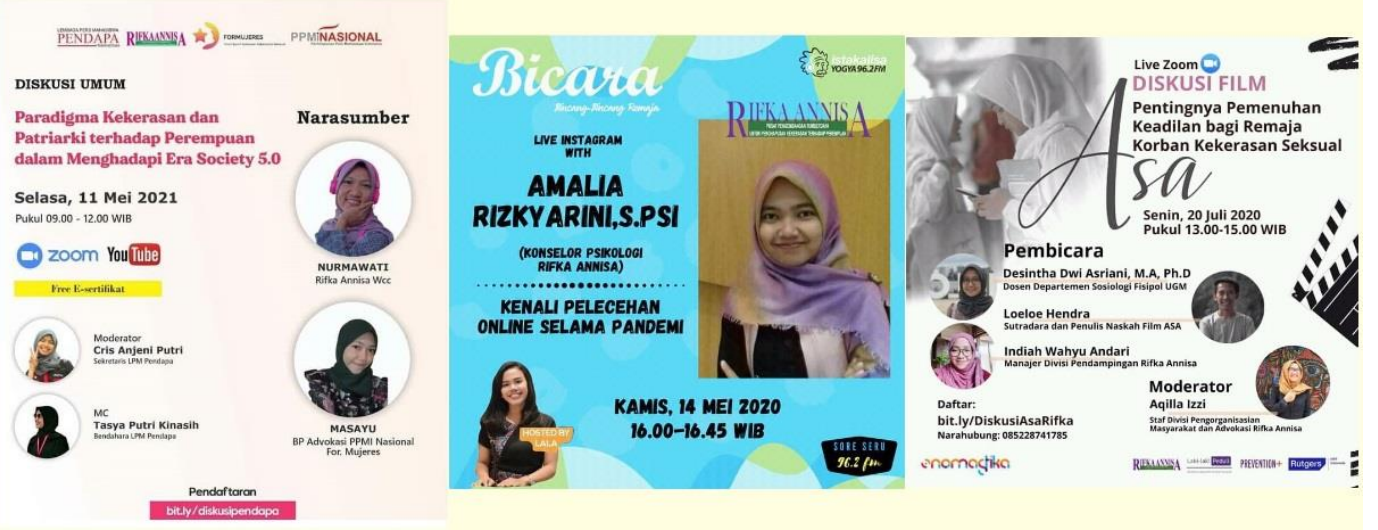

Figure 1. Example of Rifka Annisa's Online Education during the Pandemic Source: Rifka Annisa Instagram Account (@rifkaannisa_wcc)

Social media platforms can be a handy tool for public relations practitioners in the non-profit sector to achieve their organizational goals. Public Relations practitioners are aware of the effectiveness of these platforms in reaching target audiences, promoting specific goals, and developing communication strategies (Curtis et al., 2009). As shown in Figure 1, Rifka Annisa packs its educational activities through social media platforms familiar to young people, namely Instagram, Youtube, and Zoom, and displays simple layouts and sentences that are easy to understand. They also deliver educational materials in creative ways, such as through short films uploaded on the Youtube channel, as young people tend to be interested in movies.

In addition to online workshops and creative webinars, public awareness advocacy is also carried out by Rifka Annisa through Instagram and Facebook posts. The posts contain educational information in the discourse of violence against women and children, such as information on the types of violence related, the impact on victims, how to handle or prevent it, and infographics to strengthen the material presented. The Public Relations Division of Rifka Annisa chooses the Instagram platform to reach young people, as nowadays young people tend to use Instagram more as the main media for finding information. They also prefer information that is easy to digest and has many animated features or moving images (Hruska \& Maresova, 2020; Huang \& Su, 2018). Reading this behavior trend, Rifka Annisa's Public Relations and Creative Media divisions constantly generate ideas in updating their social media post so that young people can fully understand the information and the message conveyed. In contrast to Instagram, Rifka Annisa uses the Facebook platform to reach young adults and parents who have different patterns in finding and consuming information. Several examples of information presented on their Instagram and Facebook accounts are as follows: 


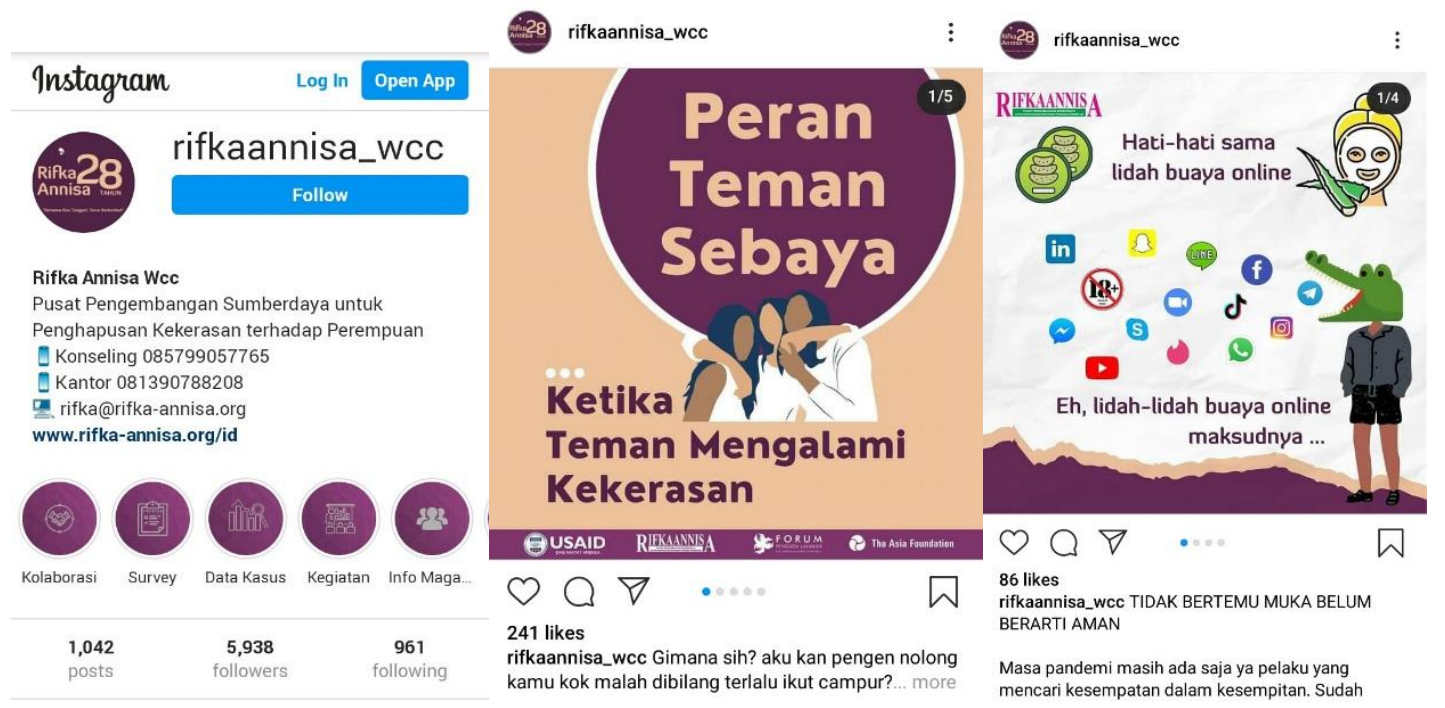

Figure 2. Example of Rifka Annisa's Instagram content

Source: Rifka Annisa Instagram Account (@rifkaannisa_wcc)

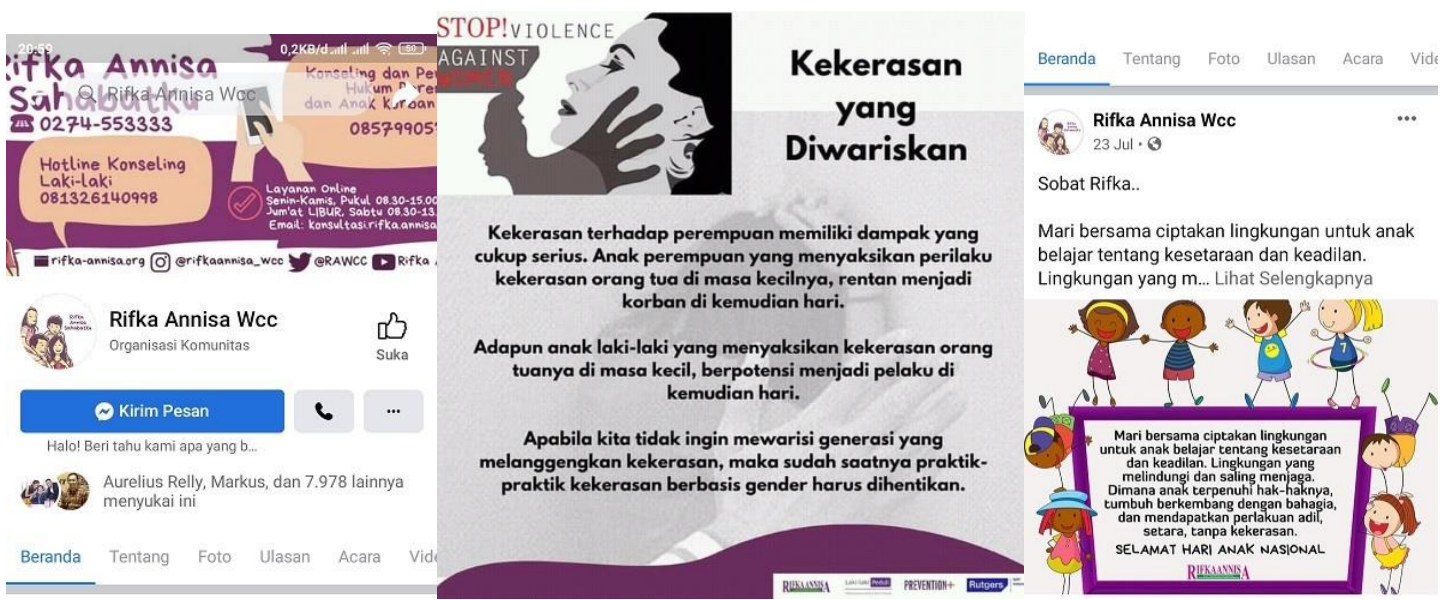

Figure 3. Example of Rifka Annisa's Facebook content Source: Rifka Annisa Facebook Account (Rifka Annisa Wcc)

The many numbers of followers, likes, and comments on Rifka Annisa's social media accounts (shown in figure 2 and 3 ) indicates a good response from the public to be more concerned about gender-based violence faced by vulnerable communities, as the informant stated,

"We saw that young people are more interested and quicker to react when they find information through social media contents. For example, when we post educational materials on Instagram, our direct messages are flooded by many college students actively asking questions, even if the discussion continues to $e$ mail. Moreover, young people are now more critical, and they want to know a lot. When we facilitate education through social media, it turns out that many young people open up to us, sharing their experiences that are similar to the ones we post, such as toxic relationships, how to have healthy relationships, etc."

Such public responses show the achievement of the objectives of the Rifka Annisa work program in educating the public, even in social limitations during the ongoing 
pandemic. Although Rifka Annisa had used social media to expand its reach to the public before the pandemic, diverting all public education activities to online platforms due to the consequences of the pandemic was a new challenge for this institution. The informant stated that when the pandemic struck in the first place, the Public Relations Division of Rifka Annisa had to adapt to a fairly heavy work rhythm in facilitating various online educational content such as podcasts, webinars, and socializing changes in consulting services to electronic media. Building a solid integration with all internal divisions to generate creative ideas and implement them in work programs is a strategic step taken by the Public Relations Division of Rifka Annisa in facing challenges during the pandemic; thus, the obstacles do not turn into crises.

\section{Conclusion}

Among many social problems that have arisen due to the outbreak of the Covid-19 pandemic, gender-based violence cannot be ignored. Cases of violence against women and children have increased globally during the Covid-19 pandemic. In most countries, Non-Governmental Organization (NGOs) contributes significantly in overcoming this social problem. This research examines the Public Relations of women's NGO Rifka Annisa in dealing with the issue of gender-based violence during the Covid-19 pandemic in Yogyakarta.

Several previous studies have examined the contribution of Public Relations in the NGO sector, including NGOs which engaged in the discourse of gender-based violence. However, the researchers did not find specific research on the performance of Public Relations in NGOs in overcoming the discourse of violence against women during the Covid-19 pandemic or research that specifically discussed the use of online media in this discourse. Therefore, the novelty of this research is examining the implementation of Rifka Annisa's Public Relations crisis management measures in finding strategic solutions to overcome obstacles that arise during the pandemic and the use of social media as part of the strategic solution taken by Rifka Annisa.

The declining economic conditions due to the Covid-19 pandemic often cause stress to the head of the household, which then triggers an increase in violence against women and children. In addition, the case of cyber-based violence has also increased because people tend to spend more time interacting in virtual spaces during the pandemic. This condition becomes more complicated because the social distancing policy limits Rifka Annisa to reach out to violence victims face-to-face and advocate for public awareness. Rifka Annisa's Public Relations Division responds to the problem by shifting its activities to online platforms. Rifka Annisa opens intensive personal counseling services through telephone lines, WhatsApp applications, and e-mail to reach out to violence victims. They also carried out public education through social media platforms including Facebook, Instagram, Youtube, and Zoom. The type of social media platform is chosen based on the suitability of the target audiences. Education material is presented in webinars and creative content. Many feedbacks on Rifka Annisa's social media accounts indicate a good response from the public to be more concerned about gender-based violence.

Making the best use of online media features in a targeted manner is Rifka Annisa's strategic solution in reaching out to the public. However, adapting to a new work rhythm during a pandemic is not easy to achieve instantly. Being observant in identifying problems, building solid integration, and maximizing the performance of each division to generate creative ideas that are then implemented into work programs 
are the strategic steps Rifka Annisa to face the challenges during the pandemic. Thus, the problems do not develop into crises.

\section{References}

Aldoory, L., Kim, J., \& Tindall, N. (2010). The influence of perceived shared risk in crisis communication: Elaborating the situational theory of publics. Public Relations Review, 36(2), 134-140.

Ali, H. M., Boddy, J., O'Leary, P., \& Ewart, J. (2016). Exploring the use of public relations in organising activism: Implications for addressing gender-based violence in the developing world. Asia Pacific Public Relations Journal, 17(2), 46-61. https://nova.newcastle.edu.au/apprj

Andina, J.R., Marvel, T., Wirahman, D.P. (2020). The Correlation between the Covid19 Pandemic and Domestic Abuse against Women: A Comparative Study Between Australia, Indonesia, and India. Jurnal Sentris, 1(2), 109-124. https://doi.org/10.26593/sentris.v1i2.4291.109-124

Ardianto, E. (2011). Komunikasi Massa Suatu Pengatar. Bandung: Simbiosa Rekatama.

Baruah, T. D. (2012). Effectiveness of Social Media as a tool of communication and its potential for technology enabled connections: A micro-level study. International Journal of Scientific and Research Publications, 2(5), 1-10. ISSN 2250-3153

Bhati, D. A. (2013). Role of Public Relations for Effective Communications in NGOs. International Journal of Scientific Research, 2(11), 338-340. https://doi.org/10.15373/22778179/nov2013/107

Cea, K., Silalahi, R.R., Nadya, R. (2020). Strategi Manajemen Krisis Public Relations Komisi Perlindungan Anak Indonesia (Kpai). MEDIASI - Jurnal Kajian dan Terapan Media, Bahasa, Komunikasi 1(3), 228-236. https://ojs2.polimedia.ac.id/index.php/mediasi/article/download/144/101

Curtis, L., Edwards, C., Fraser, K. L., Gudelsky, S., Holmquist, J., Thornton, K., \& Sweetser, K. D. (2010). Adoption of social media for public relations by nonprofit organizations. Public Relations Review, 36(1), 90-92. https://doi.org/10.1016/j.pubrev.2009.10.003

Devlin, E. S. (2006). Crisis Management Planning and Execution (1st ed.). Auerbach Publications.

Devries K, Knight L, Petzold M, et al. (2018). Who perpetrates violence against children? A systematic analysis of age-specific and sex-specific data. BMJ Paediatrics Open, 2(1), 1-15. http://dx.doi.org/10.1136/bmjpo-2017-000180

Fajar, A. (2011). Sistem Kendali dan Strategi Penanganan (Manajemen) Krisis Dalam Kajian Public Relations. Jurnal ASPIKOM, 1(3), 279-286. http://dx.doi.org/10.24329/aspikom.v1i3.25

Greig, A. (2016). Self-Learning Booklet: Understanding Masculinities and Violence against Women and Girls. UN Women Training Center. https://trainingcentre.unwomen.org/RESOURCES_LIBRARY/Resources_Centre/ masculinities\%20booklet\%20.pdf

Hayati, N. (2021). Media Sosial Dan Kekerasan Berbasis Gender Online Selama $\begin{array}{llll}\text { Pandemi Covid-19. HUMAYA 43-52. } & \text { 1(1), }\end{array}$ https://doi.org/10.33830/humaya.v1i1.1858.2021

Hruska, J., \& Maresova, P. (2020). Use of Social Media Platforms among Adults in the United States-Behavior on Social Media. Societies, 10(1), 27. https://doi.org/10.3390/soc10010027 
Huang, Y. T., \& Su, S. F. (2018). Motives for Instagram Use and Topics of Interest $\begin{array}{lllll}\text { among Young Adults. Future Internet, } & \text { 10(8), }\end{array}$ https://doi.org/10.3390/fi10080077

Jatmiko, M. I., Syukron, M., Mekarsari, Y. (2020). Covid-19, Harassment and Social Media: A Study of Gender-Based Violence Facilitated by Technology During the Pandemic. The Journal of Society and Media, 4(2), 319-347. https://doi.org/10.26740/jsm.v4n2.p319-347

Junaedi, F., \& Sukmono, F. (2020). University Students Behavior in Searching and Disseminating COVID-19 Online Information. Jurnal ASPIKOM, 5(2), 245-253. http://dx.doi.org/10.24329/aspikom.v5i2.767

Kaleel, A. K. K. (2020). Role of public relations in crisis management with the coronavirus crisis as an example: A case study on the UAE. International Journal of Innovation, Creativity and Change, 14(4), 1179-1190. https://www.ijicc.net/images/Vol_14/Iss_4/14475_Kaleel_2020_E_R.pdf

Karlsen, R., \& Enjolras, B. (2016). Styles of Social Media Campaigning and Influence in a Hybrid Political Communication System. The International Journal of Press/Politics, 21(3), 338-357. https://doi.org/10.1177/1940161216645335

Kazak, M. Y., Karpenko, I. I., Korochenskiy, A. P., Polonskiy, A. V., Tiazhlov, Y. I., \& Ushakova, S. V. (2017). Educational Potential of New Media. Journal of History Culture and Art Research, 6(5), 54. https://doi.org/10.7596/taksad.v6i5.1288

Kemen PPPA. (2020). Protokol Penanganan Kasus Kekerasan terhadap Perempuan di Masa Pandemi Covid-19. https://infeksiemerging.kemkes.go.id/download/ Protokol_Penanganan_KasusKekerasan terhadap Perempuan_di Masa Pandemi_COVID-19.pdf

Komnas Perempuan. (2020). Siaran Pers dan Lembar Fakta Komnas Perempuan: Catatan Tahunan Kekerasan terhadap Perempuan 2020. https://komnasperempuan.go.id/siaran-pers-detail/siaran-pers-dan-lembar-faktakomnas-perempuan-catatan-tahunan-kekerasan-terhadap-perempuan-2020

Kriyantono, R. (2015). Public Relations, Issue \& Krisis Manajemen. Jakarta: Prenada.

Mas'udah, S., Megasari, L.A., Saud, M. 2021.Women's Resistance to Domestic Violence during Covid-19 Pandemic: A Study From Indonesia. Jurnal Sosiologi Dialektika 6(12, 163-174. http://dx.doi.org/10.20473/jsd.v16i2.2021.163-174

McQuail, D. (2003). Teori Komunikasi Massa: Suatu Pengantar. Jakarta: Erlangga.

Miles, M. B., Huberman, M. A., \& Saldana, J. (2014). Qualitative Data Analysis: A Methods Sourcebook (3rd ed.). SAGE Publications, Inc.

Nasution, L.A. \& Fitriana, L.A. (2020). Factors Affecting Violence against Women during the COVID-19 pandemic: A Systematic Review: Studi Kasus. Jurnal Pendidikan Keperawatan Indonesia 6(2), 171-177. https://doi.org/10.17509/jpki.v6i2.30086

Nova, F. (2011). Crisis Public Relation. Jakarta: PT. Raja Grafindo Persada.

Pearson, I., Butler, N., Yelgezekova, Z., Nihlén, S., Yordi Aguirre, I., Quigg, Z., \& Stöckl, H. (2021). Emerging responses implemented to prevent and respond to violence against women and children in WHO European member states during the COVID-19 pandemic: a scoping review of online media reports. BMJ Open, 11(4), e045872. https://doi.org/10.1136/bmjopen-2020-045872

Rahardjo, T. (2011). Isu-isu Teoritis Media Sosial. In Junaedi, F (Ed). (2011). Komunikasi 2.0: Teoritisasi dan Implikasi, 2-28. Yogyakarta: ASPIKOM.

Raudeliūnienė, J., Davidavičienè, V., Tvaronavičienė, M., \& Jonuška, L. (2018). 
Evaluation of Advertising Campaigns on Social Media Networks. Sustainability, 10(4), 973. https://doi.org/10.3390/su10040973

Sri, A. S., Das, P., Gnanapragasam, S., \& Persaud, A. (2021). COVID-19 and the violence against women and girls: 'The shadow pandemic.' International Journal of Social Psychiatry, 67(8), 971-973. https://doi.org/10.1177/0020764021995556

Usta, J., Murr, H., El-Jarrah, R. (2021). COVID-19 Lockdown and the Increased Violence Against Women: Understanding Domestic Violence During a Pandemic. Violence and Gender, 8(3), 133-139. http://doi.org/10.1089/vio.2020.0069 